Original Research Paper

\title{
Peningkatan Pemahaman Masyarakat terhadap Bahaya dan Dampak Bencana Alam Serta Penanggulangannya
}

\author{
Taufiq Al Ashfahani Qodrifuddin'1, Jumiati' ${ }^{1}$ Kartini' ${ }^{1}$ Maya Zulva1 ${ }^{1}$, Mihratun', Rakyal Aini', \\ Rina Kumala Utami ${ }^{1}$, Siska febri Cahyani, ${ }^{1}$ Uli Aprialis ${ }^{1}$, Baiq Nilam Safitri ${ }^{2}$, Widiami Sayidah ${ }^{3}$, \\ Ahmad Raksun ${ }^{*}$ \\ ${ }^{1}$ Program Studi Pendidikan Guru Sekolah Dasar, FKIP, Universitas Mataram, Indonesia \\ ${ }^{2}$ Program Studi Pendidikan Bahasa Inggris, FKIP, Universitas Mataram, Indonesia \\ ${ }^{3}$ Program Studi Pendidikan Matematika, FKIP, Universitas Mataram, Indonesia \\ ${ }^{4}$ Program Studi Pendidikan Biologi, FKIP, Universitas Mataram, Indonesia
}

https://doi.org/10.29303/jpmpi.v3i2.1400

Sitasi: Qodrifuddin, T. A. A., Jumiati., Kartini., Zulva, M., Mihratun., Aini, R., Utami, R. K., Cahyani, S. F., Aprialis, U., Safitri, B. N., Sayidah, W \& Raksun, A. (2022). Peningkatan Pemahaman Masyarakat terhadap Bahaya dan Dampak Bencana Alam Serta Penanggulangannya. Jurnal Pengabdian Magister Pendidikan IPA, 5(1)

\section{Article history}

Received: 11 Januari 2022

Revised: 01 Februari 2022

Accepted: 07 Februari 2022

*Corresponding Author: Ahmad Raksun, Program Studi Pendidikan Biologi, FKIP, Universitas Mataram, Indonesia;

Email :

ahmadunram@unram.ac.id

\begin{abstract}
Indonesia sebagai negara kepulauan, memiliki karakteristik geografis beragam baik secara tatanan tektonik, dinamika meteorologis, maupun klimatologis yang rawan terhadap bencana alam. Salah satu penyebabnya adalah karena wilayah Indonesia dilalui oleh dua jalur gunung berapi dunia, sirkum pasifik (Pacific ring of fire) dan sirkum Mediterania yang melintasi wilayah Pulau Sumatera, Jawa, Nusa Tenggara, hingga Sulawesi Utara. Bencana yang mungkin terjadi sangatlah beragam yakni gempa bumi, tsunami dan gunung meletus. Selain itu karena banyaknya daerah pegunungan dan pemukiman yang padat penduduk juga dapat menyebabkan timbulnya bencana alam banjir dan tanah longsor. Untuk mengantisipasi kepanikan dan ketidak siagaan masyarakat maka dilakukan sosialisasi bersama mahasiswa KKN dengan BPBD (Badan Penanggulangan Bencana Daerah), guna mengedukasi masyarakat tentang bencana alam serta berbagai hal yang perlu dilakukan sebagai pembelajaran dan perkenalan awal pada mitigasi bencana. Kegiatan ini diharapkan dapat menambah pengetahuan dan wawasan masyarakat di bidang bencana dan mengetahui tindakan yang perlu dilakukan saat terjadi bencana alam serta evakuasi mayarakat untuk meniadakan atau mengurangi dampak bencana.
\end{abstract}

Keywords: Peningkatan pemahaman masyarakat, bahaya bencana alam

\section{Pendahuluan}

Bencana alam adalah bencana yang diakibatkan oleh peristiwa atau serangkaian peristiwa yang disebabkan oleh alam, antara lain: berupa banjir, tanah longsor, gempa bumi, tsunami, gunung meletus, kekeringan, dan angin topan (Pasal 1 UU No.24 Tahun 2007). Bencana alam merupakan peristiwa alam yang mengakibatkan dampak besar bagi manusia. Korban dapat berupa perorangan, keluarga atau kelompok masyarakat yang menderita baik secara fisik, mental, maupun sosial ekonomi. Sebagai akibat dari terjadinya bencana, menyebabkan mereka mengalami hambatan dalam melaksanakan tugas kehidupannya. Permasalahan utama yang dihadapkan pada masyarakat secara umum ialah kurangnya pemahaman tentang 
bencana dan kesigapan terhadap bencana, menganggap mudah permasalahan seputar kebencanaan, akibatnya berdampak ketidakpedulian masyarakat terhadap kondisi lingkungan serta alam. Indonesia sebagai negara kepulauan, memiliki karakteristik geografis beragam baik secara tatanan tektonik, dinamika meteorologis, maupun klimatologis yang rawan terhadap bencana alam. Selama satu tahun terakhir (1 Januani -30 September 2021), sebuah riset yang dilakukan oleh BNPB (Badan Nasional Penanggulangan Bencana) menunjukkan bahwa di Indonesia telah terjadi bencana alam besar sebanyak 1.969 kali.

Secara keseluruhan, bencana tersebut telah menelan korban jiwa sebanyak 519 orang, 74 dinyatakan menghilang dan 6.208.250 jiwa dalam kondisi menderita atau mengungsi serta 12.901 lainnya luka-luka. Daerah Indonesia beresiko terjadi bencana alam, dan telah menjadi bagian dari sejarah serta menjadi isuaktual. Salah satu penyebab karena wilayah Indonesia dilalui oleh dua jalur gunung berapi dunia, sirkum pasifik (Pacific ring of fire) dan sirkum Mediterania yang melintasi wilayah Pulau Sumatera, Jawa, Nusa Tenggara, hingga Sulawesi Utara. Jenis dan jumlah bencana alam besar yang terjadi tahun 2021 untuk menjadi gambaran kondisi, sebagaimana tersebut dalam gambar 1. Menyikapi fakta kebencanaan tersebut, banjir merupakan bencana yang sering terjadi. Merujuk pada pengalaman negara-negara Eropa, seperti Perancis menyikapi keselamatan sipil merupakan hak individu yang penting dan harus dijamin, keselamatan sipil sama pentingnya dengan pengakuan terhadap kebebasan individu dan kepemilikan pribadi, masyarakat terutama korban berhak mendapatkan perlindungan atas jiwa dan hak miliknya.

Oleh karena itu, resiko bencana harus diminimalisir, dan secara moral jatuhnya korban tidak dapat ditolerir. Pemerintah menempatkan persoalan bencana alam menjadi salah satu prioritas penanganan. Berkait dengan hal tersebut, lembaga legislatif pada bulan April 2007 mengesahkan dua undang-undang, UndangUndang Penanggulangan Bencana (UU No. 24 tahun 2007) dan Undang- Undang Penataan Ruang (UU No. 26 tahun 2007) yang merupakan revisi dari undang- undang sebelumnya, yaitu Nomor 24 tahun 1992 yang menunjukkan, bahwa kebijakan penanganan resiko bencana ditangani secara komprehensif dan dititikberatkan pada upaya preventif, yaitu tidak hanya pada saat terjadinya bencana alam.

Gambar 1. Dampak bencana alam 202

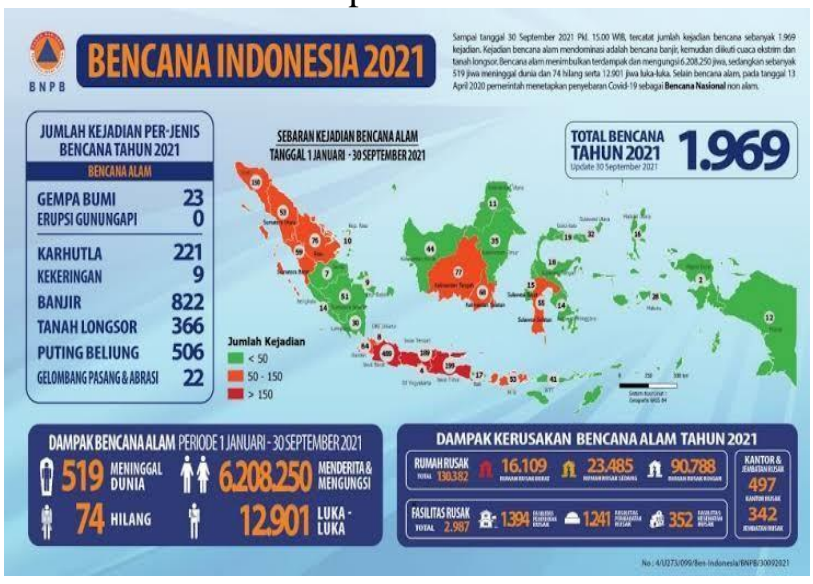

Sehingga idealnya masyarakat secara umum sudah mampu menangani bencana sebelum,saat dan sesudah bencana. Masyarakat memiliki kemampuan untuk mengenali ancaman di wilayahnya dan mampu mengorganisir sumber daya masyarakat untuk mengurangi kerentanan dan sekaligus meningkatkan kapasitas demi mengurangi risiko bencana. Kemampuan ini diwujudkan dalam perencanaan pembangunan yang mengandung upaya- upaya pencegahan, kesiap siagaan, pengurangan risiko bencana dan peningkatan kapasitas untuk pemulihan pascabencana (Munita, 2015).

Desa Ekas Buana merupakan salah satu desa di kecamatan Jerowaru, Kabupaten Lombok Timur, Provinsi Nusa Tenggara Barat t dengan posisi geografi pada $8^{\circ} 49^{\prime} 7^{\prime \prime}$ LS dan $116^{\circ} 28^{\prime} 16^{\prime \prime}$ BT dengan ketinggian $3 \mathrm{mdpl}$. Secara administrasi desa Ekas Buana berbatasan langsung dengan, Sebelah utara ; Desa pemongkong, Sebelah selatan; Kuang Rundun, Sebelah timur ; Desa Seriwe, Sebelah barat ; Laut Teluk Ekas. Desa Ekas Buana terdiri atas 5 Dusun, yakni ; Dusun Ekas, Dusun Ekas Damai, Dusun Sungkun, Dusun Lendang Terak dan Dusun Kuang Adil. Jarak Desa Ekas Buana dengan Ibu Kota Kecamatan Jerowaru yaitu 15 $\mathrm{km}$ dapat ditempuh dalam waktu \pm 30 menit dengan kendaraan bermotor. Sedangkan jarak ke 
Ibu Kota Kabupaten Lombok Timur yaitu 35 km dapat ditempuh dalam waktu \pm 2 jam dengan kendaraan bermotor. Desa Ekas Buana memiliki curah hujan mencapai $30 \mathrm{~mm}$ dengan jumlah bulan hujan adalah 3 bulan dengan kelembapan 0,4 dan suhu rata-rata harian adalah $30^{\circ} \mathrm{C}$ (Profil Desa Ekas Buana 2021).

Sebagian besar mata pencaharian penduduk Desa Ekas Buana sebagai nelayan, hal ini di karenakan letak desa yang dekat dengan area pesisir pantai . Terdapat banyak bangunan yang di bangun sepanjang pesisir pantai yang hanya berjarak 20-30m dari tepian, hal ini menyebabkan beberapa area yang dekat dengan teluk ekas terendam oleh banjir rob setiap dua tahun sekali pada pertengahan bulan desember.

Berbeda dengan banjir yang disebabkan oleh hujan deras yang berlangsung terus menerus, banjir rob berhubungan dengan permukaan dan air laut. Banjir rob adalah peristiwa naiknya permukaaan laut atau air laut ke daratan, yang disebabkan oleh air laut pasang. Karena naiknya permukaan air laut ke daratan inilah yang kemudian menyebabkan daerah di sekitarnya jadi tergenang atau mengalami banjir.

Melihat dari tatanan pemukiman di desa ekas terutama pada dusun ekas, rumah yang di bangun terlalu dekat dengan area pesisir pantai,banyaknya pembangunan yang menjadi penyebab turunnya permukaan tanah yang disebabkan air tanah yang terlalu banyak diambil. Selain itu melihat pada iklim di wilayah indonesia sekarang sering terjadi perubahan iklim yang nantinya badai maupun angin topan akan semakin terjadi.

Upaya untuk meningkatkan kesadaran dan kesigapan masyarakat desa yang tinggal di pesisir pantai maka diberikan kegiatan sosialisasi tanggap bencana bersama dengan BPBD, serta papan informasi kesigapan bencana. Yang diharapkan mampu memberikan pemahaman kebencanaan sebelum,saat dan sesudah bencana agar mengantisipasi tingkat kerusakan baik secara mental akibat kepanikan dan rasa gelisah serta takut maupun kerusakan pada harta benda akibat kurangnya kesigapan menerima tanda-tanda akan bencana.

\section{Metode}

Metode yang digunakan pada program ini demplot atau sosialisasi yang ditunjukan untuk meningkatkan pengetahuan dalam mengoptimalikan respon terhadap tanda-tanda akan bencana, yang diberikan materi seputar bencana oleh BPBD terkait tahapan yang dilakukan saat dihadapkan dengan situasi darurat bencana. Ada beberapa tahapan kegiatan yang dilaksanakan dalam sosialisasi tanggap bencana antara lain yaitu: 1). Perencanaan dan penentuan target sasaran desa tanggap bencana 2). Pembuatan surat undangan dan pengantaran surat ke kawil Dusun ekas 3). Pelaksanaan sosialisasi 4). Perbaikan lokasi dampak bencana.

\section{Hasil dan Pembahasan}

Salah satu tujuan sosialisasi ialah memberikan pemahaman dasar kepada masyarakat tentang bencana alam, dampak dari bencana alam serta mengantisipasi terjadinya bencana alam dan kegiatan ini juga dikemas dalam bentuk sosialisasi bersama BPBD (Badan Penanggulangan Buana pada umumnya sudah tentu mengetahui secara naruliah saat berhadapan dengan bencana mereka akan lari arah bukit yang berada paling dekat dengan pemukiman mereka.

Akan tetapi hal tersebut tidaklah cukup, hal terpenting dalam menghadapi bencana ialah bagaimana cara merespon tanda-tanda akan bencana, seperti jika dirasa suasana alam terlihat gelap di sertai angin kencang yang tidak biasa, segeralah mencari informasi siaga bencana setempat atau mencari informasi cuaca dari BMKG melalui situs resminya.

Dalam bersosialisasi seputar kebencanaan masyarakat menerima beberapa pengetahuan yakni; 1) yang dimulai dari ranah keluarga untuk mengetahui ancaman,resiko,serta cara menghindari dan mencegah bencana. 2) menyadari bahwa masyarakat tinggal diwilayah rawan bencana dan menyesuaikan diri dari bencana dan menyesuaikan diri misalnya membangun rumah tahan gempa dll. 3) berperilaku selaras dengan prinsip pengurangan resiko bencana seperti membuang sampah pada tempatnya, menanam pohon dan merawatnya serta 4) selalu siap siaga menghadapi 
bencana,mampu menghindar dan cepat pulih dari dampak bencana. Dengan sosialisasi ini diharapkan peningkatan pemahaman dan kesigapan masyarakat dalam menghadapi bencana di desa ekas buana, kecamatan jerowaru, kabupaten lombok timur.

Berikut tampilan gambar sosialisasi yang dilakukan.

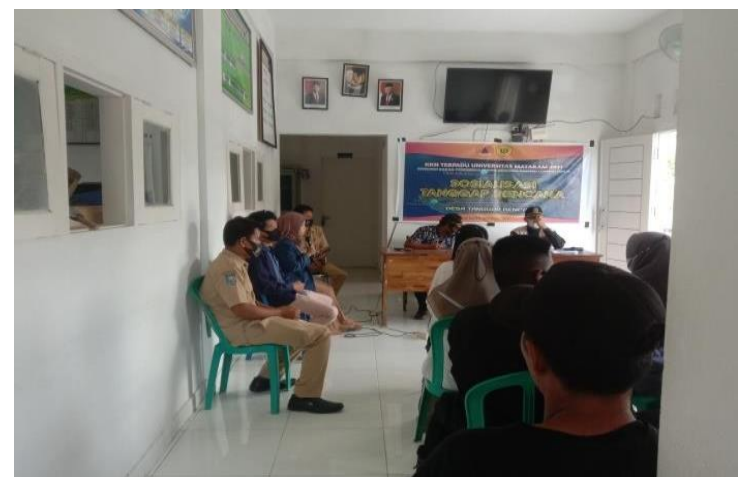

Gambar 2. Sosialisasi BPBD bersama masyarakat dan anggota keamanan desa

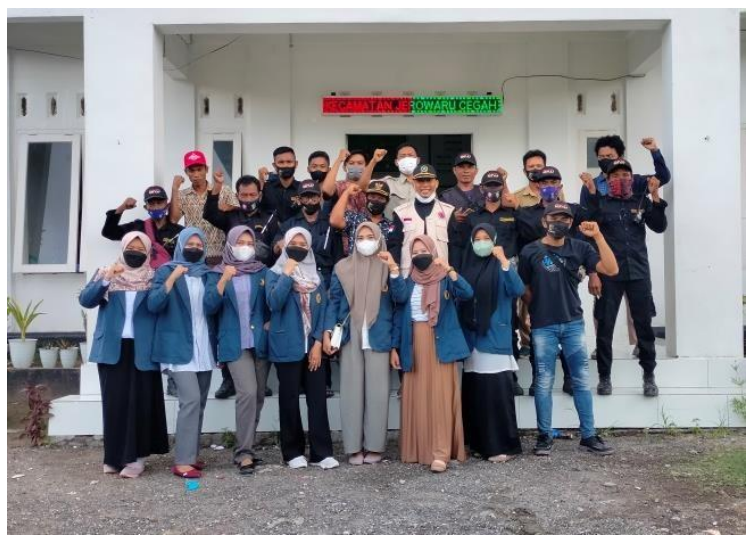

Gambar 3. Sesi Foto Bersama

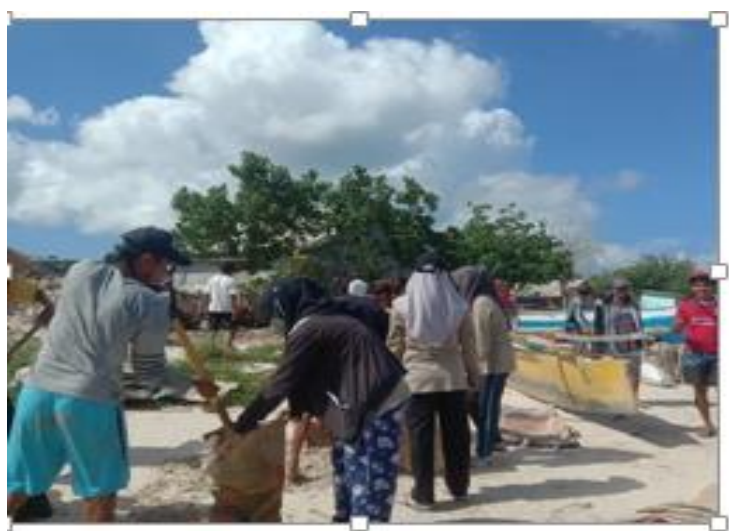

Gambar 4. Kegiatan perbaikan lokasi dampak bencana

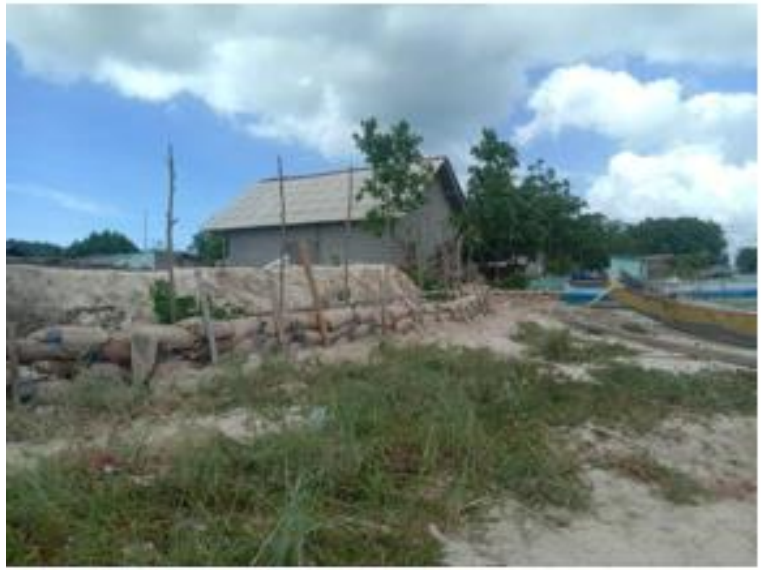

Gambar 5. Tanggul sederhana yang dibuat

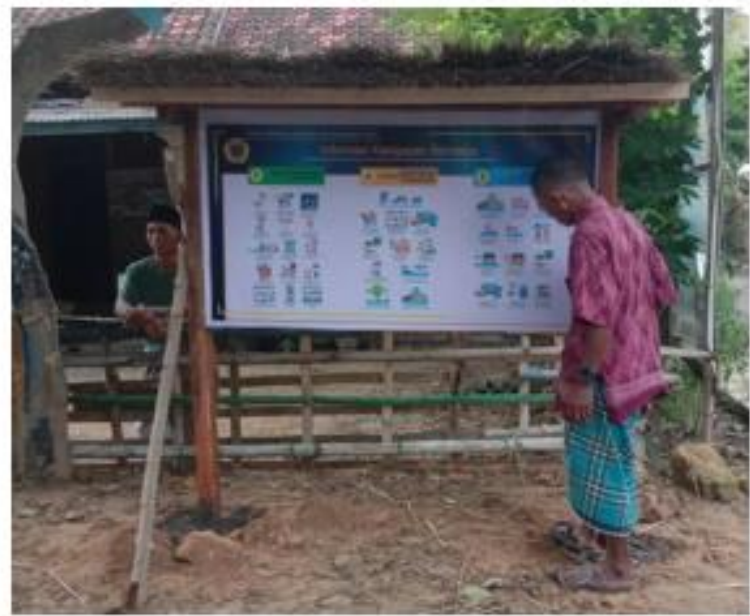

Gambar 6. Papan informasi kesigapan bencana

Kegiatan sosialisasi diharapkan akan mampu membangun pemahaman masyarakat untuk tetap waspada dan sigap dalam menghadapi bencana, baik itu bencana skala kecil maupun bencana skala besar. Kesiapsiagaan dalam menangani masalah kebencanaan mungkin dianggap sederhana dan tidak terlalu di hiraukan akan tetapi justru kesigapan dirilah yang menyelamatkan kita dari bencana.

\section{Kesimpulan}


Indonesia merupakan negeri dengan potensi bencana alam yang sangat tinggi khususnya bencana gempa bumi, letusan gunung berapi, tsunami, tanah longsor maupun banjir. Guna mengurangi dampak bencana badan nasional penanggulangan bencana (BNPB) melalui badan penanggulangan bencana daerah (BPBD) melakukan sosialisasi dan mitigasi bencana serta perbaikan dampak bencana di daerah pesisir yang terkena banjir rob desa ekas buana.

Guna mengedukasi bencana sangat perlu dilakukan sebagai pembelajaran dan perkenalan awal pada mitigasi bencana yang diharapkan sosialisasi ini para peserta dapat menambah pengetahuan di bidang bencana dan mengetahui tindakan ynag harus dilakukan saat evakuasi terjadi

\section{Ucapan Terimakasih}

Terima kasih sebesar besarnya kami ucapkan kepada seluruh pihak yang telah membantu dalam menjalankan kegiatan kepada masyarakat ini, diantaranya: (1) masyarakat Desa ekas buana atas kerjasama dan partisipasinya dalam pelaksanaan kegiatan ini, (2) BPBD yang bersedia memberikan materi tentang kebencanaan bersama anggota KKN TERPADU yang telah bekerja keras selama KKN bersama 45 hari di desa ekas buana, kecamatan Jerowaru, kabupaten Lombok Timur.

\section{Daftar Pustaka}

Dwi Heru Sukoco, 2006, Bencana dan Penanganannya.Jurnal Pusdiklatkesos Vol. 1 No. 2 Juni 2006: Jakarta

Gunawan, dkk. 2009. Studi Evaluatif tentang Penanggulangan Bencana Alam (Peran Tagana dalam Peningkatan Kesiapsiagaan Masyarakat untuk Mengurangi Resiko Bencana Alam). Jakarta: P3KS Press

Kodoatie. 2002. Sebab-sebab Alami Banjir. Jakarta: Pusat Pendidikan Mitigasi Bencana (P2MB) Universitas Pendidikan Indonesia
Undang-undang No. 24 Tahun 2007 tentang Penanggulangan Bencana

Undang-Undang No. 26 Tahun 2007 tentang Penataan Ruang 